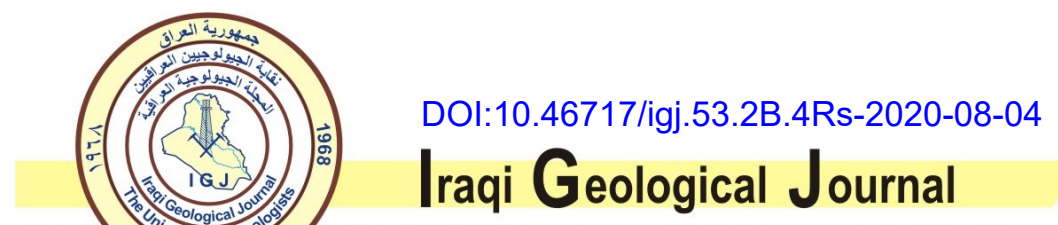

Http://igj-iraq.org

53 (2B), 2020: 71-88

ISSN 2414 - 6064

\title{
GYPSUM AND LIMESTONE DISSOLUTION WITHIN FATHA FORMATION (MIDDLE MIOCENE) AT VARIOUS pH SOLUTIONS :A LABORATORY STUDY
}

\author{
${ }^{1}$ Sahra M. Othman*, ${ }^{2}$ Saad I. Sarsam and ${ }^{3}$ Saad A. Ismail \\ ${ }^{1}$ Department of Geology, College of Science, University of Mosul, Mosul, Iraq \\ ${ }^{2}$ Department of Civil Engineering, College of Engineering, University of Baghdad, Baghdad, Iraq \\ ${ }^{3}$ Nineveh Construction Laboratory, National Center for Construction Laboratories and Researches, Mosul, Iraq \\ "E-mail: sahra.m.othman@gmail.com \\ Received: 3 February 2020; accepted: 12 June 2020
}

\begin{abstract}
The studied rocks (gypsum, limestone, \& marl) of Middle Miocene Fatha Formation situated beneath the foundations of the study site in Mosul city. These rocks were obtained from four boreholes, at various depths up to 30 meters. The aim of work is to study the dissolution of rocks at various conditions, and then obtain the effect of the dissolution on their physio-mechanical properties, in addition, to amelioration our understanding of the consequences of the dissolution by acid-sulphate solution which is indisputably linked to sulphur oxidation. Gypsum and limestone rocks (10 samples of each type of rocks) and immersed in three solutions at various $\mathrm{pH}$ environmental conditions; acidic (0.0001N $\left.\mathrm{H}_{2} \mathrm{SO}_{4}\right)$, neutral (tap water), and alkaline (0.0001N $\left.\mathrm{NaOH}\right)$ solutions. Chemical analysis results of specific elements $\left(\mathrm{Ca}^{2+}, \mathrm{Mg}^{2+}, \mathrm{Na}^{+}, \mathrm{K}^{+}, \mathrm{S}^{2-}, \mathrm{Cl}^{-}\right)$at the acidic, neutral, \& alkaline solutions show that: The dissolution (concentration of $\mathrm{Ca}^{2+} \& \mathrm{~S}^{2-}$ ) was higher in alkaline solution of gypsum rocks, while the dissolution (concentration of $\mathrm{Ca}^{2+}$ ) of the limestone rocks was higher in neutral (tap water) solution than other solutions. The physiomechanical properties of gypsum and limestone rocks samples such as, bulk specific gravity, indirect tensile strength, and unconfined compressive strength were determined. The compressive strength of water-saturated samples of gypsum rocks decreased by $25.56 \%$ and of limestone by $23.97 \%$ when compared with the dry samples, but the indirect tensile strength of water-saturated samples of gypsum rocks decreased by $36.62 \%$ and of limestone by $36.34 \%$ compared with the dry samples.
\end{abstract}

Keywords: Dissolution; Gypsum; Fatha Formation.; Limestone; Physio-mechanical 


\section{INTRODUCTION}

Dissolution of the common rocks (rock salt, gypsum, anhydrite, limestone and dolostone) produces caves, caverns, sinkholes and creating a landscape known as karsts. These rocks constitute parts of the foundations of many structures and buildings throughout the world and Iraq, so different parts of areas are suffering from karstification. In the vicinity of the Mosul city, gypsum and limestone rocks alternate with marl or claystone in cyclic nature in the Fatha Formation (Middle Miocene), Fatha rocks are highly karstified, especially the Lower Member of this Formation (Sissakian and Al-Mousawi, 2007). Parts of Mosul city built over an area where the Fatha Formation is mostly exposed. Because the continuous dissolution of gypsum and limestone beds, many buildings have collapsed after being highly cracked. In addition, roads and sewages piping continuously repaired due to continuous subsidence (Thabet et al., 1986; Adeeb, 1988). The dissolution by acid-sulphate solution, which indisputably linked to sulphur oxidation by acidophilic bacteria in the proximity of the left bank of Tigris River in the south of Mosul city (Al-Taa'i, 2002). Porcelainite and the associated Alunite and Jarosite minerals are found within the Fatha Formation and the Lower-most part of Injana Formation. These minerals are formed due to sulphuric acid seepages. The sulphuric acid $\left(\mathrm{H}_{2} \mathrm{SO}_{4}\right)$ may be produced at depth due to oxidation of sulphur $\left(\mathrm{H}_{2} \mathrm{~S}\right)$ by Thiobacillus bacteria, which raises to the surface through fractures (Jassim and Al-Naqib, 1989; AlJuboury et al., 2006). Awadh and Al-Ankaz (2016) mentioned that the depleted fluids intruded gypsum rocks of Fatha Formation; and so, the trace element concentrations in the gypsum are few.

The solubility of a substance is equal to the concentration of cation or anion (like $\mathrm{Ca}^{2+}$ in gypsum and limestone or $\mathrm{SO}_{4}{ }^{2-}$ in gypsum and $\mathrm{CO}_{3}{ }^{2-}$ in limestone) in the saturated solution, so the solubility $=\left[\mathrm{Ca}^{2+}\right]=\left[\mathrm{SO}_{4}{ }^{2-}\right]$ or $\left[\mathrm{CO}_{3}{ }^{2-}\right]($ Krauskopf, 1979). The solubility of sulphate (gypsum) or carbonates (limestone) rocks is affected by many factors like temperature, the pressure of $\mathrm{CO}_{2}, \mathrm{pH}$, the grain size of rocks, oxidation-reduction potential and the concentration of dissolved ions in solution (acid, base, salt) (Krauskopf, 1979; Lasaga et al., 1983). In general, for any salt in equilibrium with its saturated solution, the solubility is less if an excess of one of its ions is present, this decrease in the solubility of salt due to the common-ion effect. The presence of ions different from those furnished by the salt itself generally makes the salt more soluble (Krauskopf, 1979). The increase in salt content in soft soil and rocks causes a decrease in undrained shear strength and an increase in compression index, liquid limit of soft soil ( $\mathrm{Nu}$ et al., 2020). One of the most important variables that affect the solubility of minerals is $\mathrm{pH}$; the $\mathrm{pH}$ of pure water (like rainwater) in equilibrium with the 
atmosphere is $<7$, caused by dissolved $\mathrm{CO}_{2}$ forming bicarbonate ion $\left(\mathrm{HCO}_{3}{ }^{-}\right)$, carbonic acid $\left(\mathrm{H}_{2} \mathrm{CO}_{3}\right)$, and $\mathrm{H}^{+}$. This water may dissolve the calcite in limestone as the water moves along fractures and other partings or openings in the rock; this results in the dissolution of much of the limestone, and leaves behind void spaces if the reaction continues to take place over a long period of time (Martinez and White, 1999; Craft et al., 2007). Most natural waters (especially subsurface waters) evolve under conditions intermediate between open and closed systems (Langmuir, 1997). Gypsum also is highly soluble in the water, if gypsum rocks contain many cracks, so the higher number of cracks increases the dissolving rate in lesser time (Aljubouri and Khattab, 1997). The chemical composition of carbonates provides clues for the physicochemical conditions during deposition. The major oxides and some of the trace elements provide information about the overall composition of the carbonate rocks and depositional conditions to conclude the nature of seawater from which they originated (Tobia and Mustafa, 2019). The different physio-mechanical properties of limestone and gypsum rocks such as; uniaxial compressive strength, tensile strength and specific gravity, which plays an important role in the planning and designing of civil constructional works. An acidic and alkaline environment adversely affects these properties, where the rocks expose for a longer time. The rocks dissolution at different $\mathrm{pH}$ values of moisture conditions may experience a range of problems including cracking and deforming. These lead to crush and weakened rocks and forms many subsurface caverns, which have increased the dangers of the site and are unfavorable for foundation (Sharma et al., 2006). Natural cavities in limestone develop by the same processes that form cavities in evaporite (gypsum) rocks, albeit much more slowly. The high solubility of gypsum permit cavities to form in days to years, whereas cavity formation in limestone bedrock is a very slow process that generally occurs over centuries to millennia (Galloway et al., 1999).

The purpose of this research is to study the dissolution of gypsum and limestone rocks in a closed system (at atmospheric pressure and $28 \pm 2^{\circ} \mathrm{C}$ ), at three solutions of various $\mathrm{pH}$ environmental conditions; acidic $\left(0.0001 \mathrm{~N} \mathrm{H}_{2} \mathrm{SO}_{4}\right)$, neutral (tap water), and alkaline $(0.0001 \mathrm{~N}$ $\mathrm{NaOH})$ solutions. Then evaluating the influence of dissolution on the physio-mechanical properties of water-saturated samples in comparison with dry samples.

\section{LOCATION AND GEOLOGY}

The samples of the present study, which belong to the Middle Miocene Fatha Formation, lie beneath the construction site of a water tank project, near Al Yarmuk intersection on the western (right) side of Mosul city (Fig.1). The sediments of the Fatha Formation are exposed 
along the western (right) side of Tigris River, which divides and passes through Mosul city. The rocks of the formation are the oldest in the area of the study at the (or near) surface in small places (Adeeb, 1988; Ismail and Al-Naib, 1992). The Mosul city is situated on the transitional belt between Hemrin-Makhul, Butmah-Chemchemal Subzones, and belongs to the foothill zone of the unstable shelf units according to the Tectonic Divisions of Northern Iraq. the Fatha Formation is deposited during the middle Miocene sequence of the evaporite lagoons systems (Jassim and Buday, 2006). The Fatha Formation represents a cyclic repetition of gypsum (anhydrite), limestone and marl. However, the studied litho-log of boreholes (Fig.2) represents part of the formation; it consists of three types of rocks:

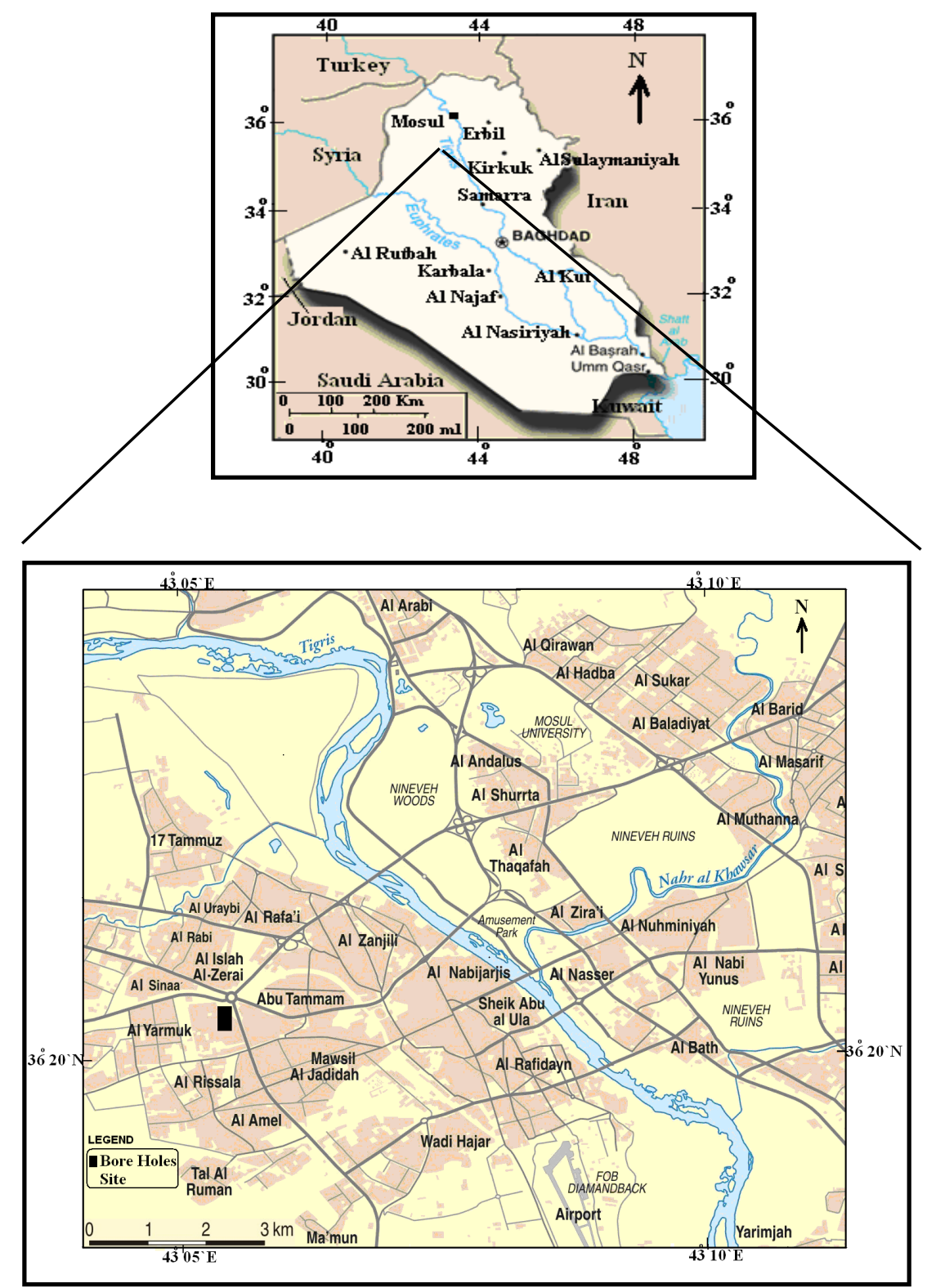

Fig. 1. Location of the studied boreholes of the Fatha Formation at Mosul city (modifying from Wikimedia Commons, 2020; ISW, 2012) 


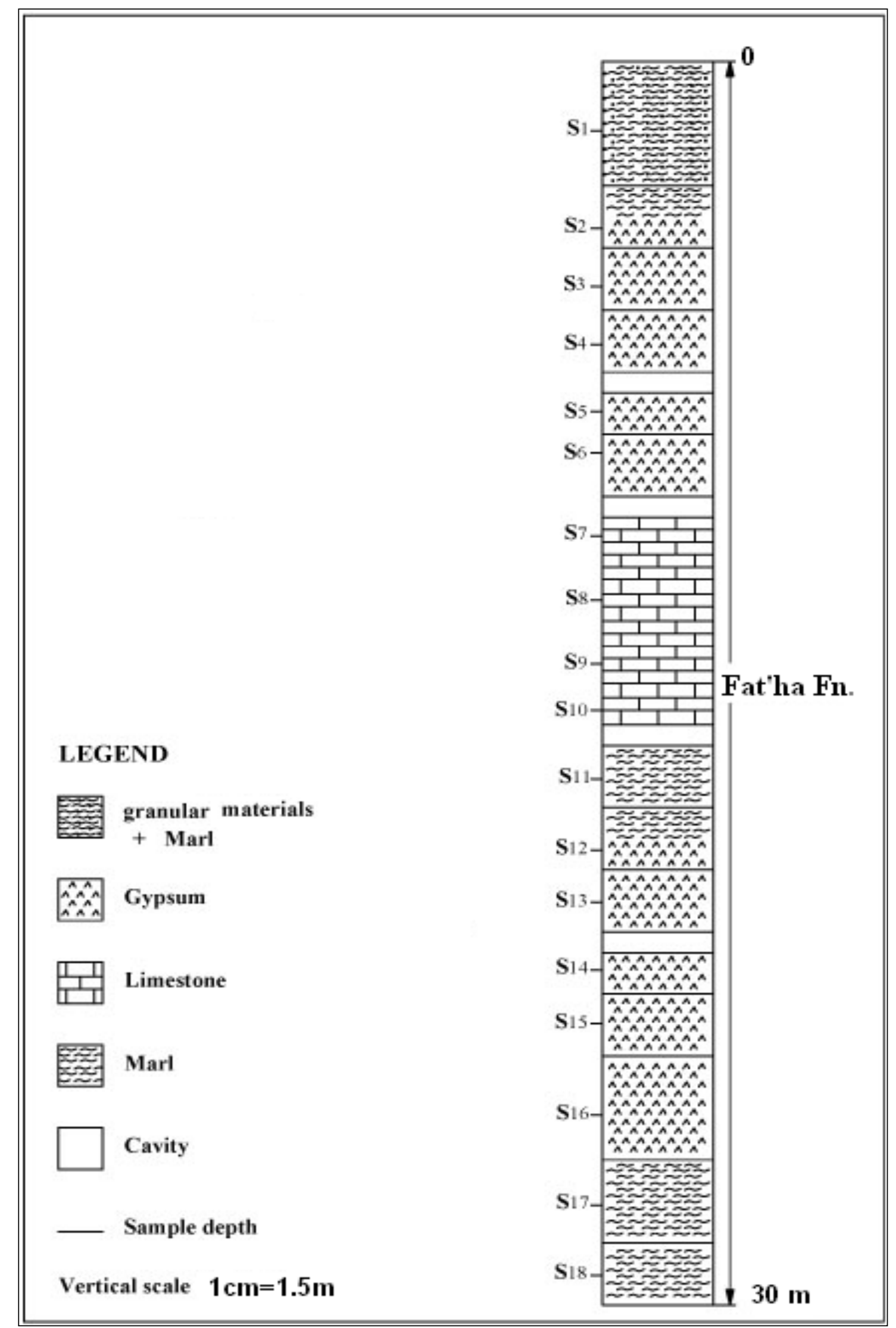

Fig. 2. Lithological column of rocks (Fatha Formation) of the studied boreholes 
- Green colour to yellow marl and thin layer repetition of marl, limestone and gypsum.

- White colour to dark grey gypsum with fractures, pockets of green marl, fragments of rocks and has cavities.

- Brown colour to grey solid limestone with fossils, high porosity and cavities.

The rock descriptions in the studied section show an indication for existence of subsurface karst features like the absence or dissolution of gypsum beds. Many gypsum horizons were not detected (cavities) during drilling (Fig.2), because they were karstified and in their places there were cavity fillings with materials, such as marl, claystone and limestone fragments (Sissakian and Abdul-Jabbar, 2005).

\section{SAMPLING AND ANALYTICAL TECHNIQUES}

Wireline coring technique implemented using a subsoil investigation-boring machine at National Center for Construction Laboratories and Researches, Baghdad, Iraq, to get continuous core samples up to 30 meters' depth (Fig.2 and Table 1). At year 1989, 72 core samples of $7.62 \mathrm{~cm}$ diameter and 1-3 meters length obtained from four boreholes of the study site. Because the lithology of core samples of four boreholes was not greatly different, so an average lithological description of bore logs of core samples shown in Table 1. At the first stage, core samples cut, and prepared for analysis and testing, using a mechanical diamondsaw at Nineveh construction laboratory, Mosul. A $7.62 \mathrm{~cm}$ diameter and 10.7-12.2 $\mathrm{cm}$ length, cores with a cylinder-ness ratio range of $1.4-1.6$ were obtained as per (ASTM D2938, 2002; ASTM D3967, 2001).

A Phillips PW 1840 XRD spectrometer (at the State Company for Geological Survey and Mining-Baghdad, Iraq) used for the mineralogical analysis of study rocks. The results are shown in Table 2, While Table 3 demonstrates the means of chemical analysis of major oxides and constituents of the bulk rock samples of the Fatha Formation, carried out by a Phillips PW 1450 XRF spectrometer and wet analysis at the State Company for Geological Survey and Mining, Baghdad, Iraq. The dissolution of gypsum and limestone rocks at various $\mathrm{pH}$ solutions studied at second stage, such solutions may represent the expected natural field conditions of underground surrounding the foundations. The core samples (D $7.62 \mathrm{~cm} \mathrm{\&} \mathrm{H}$ $11.5 \mathrm{~cm}$ ) are separated into three groups of each type of rocks, every group consists of three samples as a minimum. The core sample of the first group was immersed into an acidic solution (10 liters of dilute $\mathrm{H}_{2} \mathrm{SO}_{4}$ of $0.0001 \mathrm{~N}$ ), the core samples of the second group were immersed in 10 liters of neutral (tap water) into a plastic container, and the core samples of the third group were immersed in an alkaline solution (10 liters of dilute $\mathrm{NaOH}$ of $0.0001 \mathrm{~N}$ ). 
The plastic containers were stored at Biology Department, College of Science, Mosul University, Iraq, at atmospheric pressure (without covered the openings of containers) and at temperature $28 \pm 2^{\circ} \mathrm{C}$ with duration of about 28 days using closed system. The $\mathrm{pH}$ of the three various solutions is determined by $\mathrm{pH}-$ meter at Biology Department, College of Science, Mosul University, Iraq, during the testing.

Table 1. Lithological description of the core rocks samples (Fatha Formation) from boreholes of the present study

\begin{tabular}{|c|c|l|}
\hline Sample No. & Depth (in meter) & \multicolumn{1}{|c|}{ Lithologies } \\
\hline S1 & $0-3$ & granular materials (recent sediments) + Marl \\
\hline S2 & $3-4.5$ & Marl + Gypsum \\
\hline S3 & $4.5-6$ & Gypsum \\
\hline S4 & $6-7.5$ & Gypsum \\
\hline S5 & $7.5-8$ & Cavity \\
\hline S6 & $9-9$ & Gypsum \\
\hline S7 & $10.5-11$ & Gypsum \\
\hline S8 & $11-12.5$ & Limestone \\
\hline S9 & $12.5-13.5$ & Limestone \\
\hline S10 & $15-15$ & Limestone \\
\hline & $16-16.5$ & Cimestone \\
\hline S11 & $16.5-18$ & Cavity \\
\hline S12 & $18-19.5$ & Marl + Gypsum \\
\hline S13 & $19.5-21$ & Gypsum \\
\hline & $21-21.5$ & Cavity \\
\hline S14 & $21.5-22.5$ & Gypsum \\
\hline S15 & $22.5-24$ & Gypsum \\
\hline S16 & $24-26.5$ & Gypsum \\
\hline S17 & $26.5-28.5$ & Marl \\
\hline S18 & $28.5-30$ & Marl \\
\hline & & \\
\hline & & \\
\hline
\end{tabular}


Table 2. Mineralogical composition of the bulk rocks samples

(Fatha Formation) of the present study

\begin{tabular}{|l|l|}
\hline Rock type & Mineralogical Analysis by XRD \\
\hline Gypsum & Gypsum \\
\hline Limestone & Calcite, Dolomite, Quartz, Clay minerals (trace) \\
\hline Marl & Calcite (Dolomite), Quartz, Clay Minerals \\
\hline
\end{tabular}

Table 3. Chemical composition of the bulk rocks samples (Fatha Formation) of the studied area

\begin{tabular}{|c|c|c|c|c|c|c|c|c|}
\hline \multirow{2}{*}{$\begin{array}{c}\begin{array}{c}\text { Rock } \\
\text { type }\end{array} \\
\text { Cons } \\
\text { tituent } \\
(\%)\end{array}$} & \multicolumn{2}{|c|}{ Theoretical } & \multicolumn{3}{|c|}{ Mean } & \multicolumn{3}{|c|}{ Range } \\
\hline & 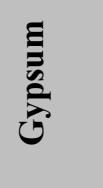 & 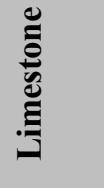 & $\begin{array}{r}\text { Gypsum } \\
(n=14)\end{array}$ & $\begin{array}{l}\text { Limestone } \\
\qquad(\mathrm{n}=\mathbf{8})\end{array}$ & $\begin{array}{l}\text { Marl } \\
(n=8)\end{array}$ & Gypsum & Limestone & Marl \\
\hline $\mathrm{CaO}$ & 32.58 & 56.03 & 31.29 & 48.55 & 16.12 & $27.83-32.43$ & $40.24-53.0$ & $6.97-28.88$ \\
\hline $\mathrm{MgO}$ & & & - & 3.41 & 6.75 & - & $0.51-11.6$ & $2.6-13.2$ \\
\hline $\mathrm{SO}_{3}$ & 46.51 & & 44.76 & - & 1.6 & $39.62-46.09$ & - & $0.15-5.4$ \\
\hline $\mathrm{H}_{2} \mathrm{O}^{+}$ & 20.91 & & 19.38 & - & - & $17.79-19.94$ & - & - \\
\hline $\mathrm{CO}_{2}$ & & 43.97 & - & - & - & - & - & - \\
\hline LOI & & & - & 41.82 & 19.95 & - & $40.09-44.07$ & $8.86-30.85$ \\
\hline IR & & & 3.61 & 3.59 & - & $0.63-16.87$ & $1.99-5.31$ & - \\
\hline $\mathrm{SiO}_{2}$ & & & - & - & 35.91 & - & - & $21.46-47.8$ \\
\hline $\mathrm{Fe}_{2} \mathrm{O}_{3}$ & & & - & - & 3.71 & - & - & $2.02-5.2$ \\
\hline $\mathrm{Al}_{2} \mathrm{O}_{3}$ & & & - & - & 9.45 & - & - & $6.0-13.88$ \\
\hline $\mathrm{TiO}_{2}$ & & & - & - & 0.92 & - & - & $0.6-1.16$ \\
\hline $\mathrm{Na}_{2} \mathrm{O}$ & & & - & - & 0.62 & - & - & $0.31-0.9$ \\
\hline $\mathrm{K}_{2} \mathrm{O}$ & & & - & - & 2.79 & - & - & $1.77-3.85$ \\
\hline Sum & 100 & 100 & 99.04 & 97.37 & 97.82 & & & \\
\hline
\end{tabular}

(n) Represented the number of samples

The concentrations of cations $\left(\mathrm{Ca}^{2+}, \mathrm{Mg}^{2+}, \mathrm{Na}^{+}, \& \mathrm{~K}^{+}\right)$of the solutions at various $\mathrm{pH}$ environments were determined at different time intervals throughout the testing according to APHA et al. (1976). Using an Atomic Absorption Instrument (Type Pye Unicamp-SP9) at the Biology Department, College of Science, Mosul University, Iraq. On the other hand, the concentrations of sulfate and chloride were determined by using wet analysis, argentometric method for chloride, and gravimetric method for sulfate according to APHA et al. (1976). At the third stage, core samples (D $7.62 \mathrm{~cm} \mathrm{\&} \mathrm{H} 11.5 \mathrm{~cm}$ ) were divided into two groups to determine the physical and mechanical properties like; bulk specific gravity according to ASTM C97 (2002), as well as the indirect tensile strength, and unconfined compressive strength. Using a universal testing machine at Nineveh construction laboratory, Mosul. The 
strain rate selected of compressive strength should produce failure in a test time between 2-15 min (ASTM D2938, 2002), while tensile test failure will occur within 1-10 min of loading or loading rate between $0.05-0.35 \mathrm{MPa} / \mathrm{Sec}$ (ASTM D3967, 2001). The first group tested after subjecting the core samples to air-drying conditioning within laboratory temperature of $20 \pm$ $2{ }^{\circ} \mathrm{C}$ for one week. The second group tested after soaking the cores in water at $20^{\circ} \mathrm{C}$ for 48 hours. The results of physical and engineering properties are shown in Table 4.

Table 4. The results of some physical and mechanical properties of the rocks samples (Fatha Formation) of the studied area

\begin{tabular}{|l|c|c|c|c|c|c|}
\hline $\begin{array}{c}\text { Physical } \\
\text { Prope } \\
\text { rty }\end{array}$ & $\begin{array}{c}\text { Dry } \\
\text { weight }\end{array}$ & $\begin{array}{c}\text { Bulk specific } \\
\text { gravity }\end{array}$ & $\begin{array}{c}\text { Compressive } \\
\text { strength - dry } \\
\text { MPa }\end{array}$ & $\begin{array}{c}\text { Compressive } \\
\text { strength - wet } \\
\text { MPa }\end{array}$ & $\begin{array}{c}\text { Tensile } \\
\text { strength - } \\
\text { dry } \\
\text { MPa }\end{array}$ & $\begin{array}{c}\text { Tensile } \\
\text { strength - } \\
\text { wet }\end{array}$ \\
MPa
\end{tabular}

(n) Represented the number of samples

\section{RESULTS AND DISCUSSION}

Table 2 illustrates the major minerals of gypsum rock (gypsum), limestone and marl (calcite, dolomite, quartz and clay minerals) of the Fatha Formation. While Table (3) shows the mean and range results of chemical analysis for the major oxides and constituents of the gypsum rock $\left(\mathrm{CaO}, \mathrm{SO}_{3}, \mathrm{H}_{2} \mathrm{O}^{+}\right.$\& IR), $\operatorname{marl}\left(\mathrm{SiO}_{2}, \mathrm{Fe}_{2} \mathrm{O}_{3}, \mathrm{Al}_{2} \mathrm{O}_{3}, \mathrm{TiO}_{2}, \mathrm{CaO}, \mathrm{MgO}, \mathrm{SO}_{3}, \mathrm{Na}_{2} \mathrm{O}, \mathrm{K}_{2} \mathrm{O} \&\right.$ LOI), and limestone ( $\mathrm{CaO}, \mathrm{MgO}, \mathrm{LOI} \& \mathrm{IR})$. It is clear that from chemical analysis of studied rocks, limestone samples have purity (78.19\%), but gypsum samples are of purity $(92.60 \%)$, which are calculated according to Aljubouri (2011). The analytical results of some elements in solutions of the three types environments (acidic, neutral (tap water), and alkaline) in closed system (at atmospheric pressure and at $28 \pm 2^{\circ} \mathrm{C}$ ) of gypsum and limestone rocks samples are shown in Table 5 and Table 6 respectively. 
Table 5. The average concentrations of some of the common elements in various solutions at different times in (10) gypsum rock samples (1S3, 2S3, 1S4, 1S5, 1S6, 1S13, 1S14, 1S15, 2S15 and 1S16) of the Fatha Formation

\begin{tabular}{|c|c|c|c|c|c|c|c|c|}
\hline $\begin{array}{l}\text { Solution } \\
\text { Type }\end{array}$ & $\begin{array}{c}\mathrm{pH} \\
\text { at } 28 \\
\pm 2^{\circ} \mathrm{C}\end{array}$ & $\begin{array}{l}\text { Element } \\
\text { (dime }\end{array}$ & $\begin{array}{l}\mathrm{Ca}^{2+} \\
\mathrm{ppm}\end{array}$ & $\begin{array}{l}\mathrm{Mg}^{2+} \\
\mathrm{Ppm}\end{array}$ & $\begin{array}{l}\mathrm{Na}^{+} \\
\mathrm{ppm}\end{array}$ & $\begin{array}{c}\mathrm{K}^{+} \\
\mathrm{Ppm}\end{array}$ & $\begin{array}{c}\mathrm{S}^{2-} \\
\mathrm{ppm}\end{array}$ & $\begin{array}{c}\mathrm{Cl}^{-} \\
\mathrm{ppm}\end{array}$ \\
\hline \multirow{5}{*}{$\begin{array}{l}\text { Acidic } \\
(0.0001 \mathrm{~N} \\
\left.\mathrm{H}_{2} \mathrm{SO}_{4}\right)\end{array}$} & \multirow{5}{*}{2.2} & 1 & 3.2 & 4.2 & 1.5 & 17.3 & 8 & 3.5 \\
\hline & & 7 & 3.3 & 4.5 & 3.5 & 17.3 & 16 & 11 \\
\hline & & 14 & 3.3 & 4.6 & 3.5 & 17.3 & 16 & 20 \\
\hline & & 21 & 3.5 & 4.8 & 3.5 & 17.3 & 16 & 21 \\
\hline & & 28 & 3.6 & 4.9 & 3.5 & 38.9 & 16 & 21 \\
\hline \multirow{5}{*}{$\begin{array}{l}\text { Neutral } \\
\text { (Tap Water) }\end{array}$} & \multirow{5}{*}{7.2} & 1 & 2.3 & 6.8 & 1.9 & 17.3 & 4.4 & 3.9 \\
\hline & & 7 & 4.2 & 7.3 & 2.7 & 17.3 & 4.8 & 18 \\
\hline & & 14 & 5.3 & 7.8 & 3.9 & 17.3 & 6.2 & 18.5 \\
\hline & & 21 & 6 & 9 & 4.7 & 24.5 & 6.8 & 19 \\
\hline & & 28 & 7.2 & 9 & 10.3 & 24.5 & 12 & 20 \\
\hline \multirow{5}{*}{$\begin{array}{l}\text { Alkaline } \\
(0.0001 \mathrm{~N} \\
\mathrm{NaOH})\end{array}$} & \multirow{5}{*}{10.6} & 1 & 2.4 & 4.1 & 6.7 & 17.3 & 12 & 3.4 \\
\hline & & 7 & 2.5 & 4.2 & 6.7 & 17.3 & 16 & 12 \\
\hline & & 14 & 6.2 & 4.2 & 9.9 & 17.3 & 18 & 16 \\
\hline & & 21 & 8.3 & 4.2 & 9.9 & 110.8 & 20 & 18 \\
\hline & & 28 & 11.1 & 4.2 & 9.9 & 110.8 & 22 & 20 \\
\hline
\end{tabular}

Table 6. The average concentrations of some of the common elements in various solutions at different times in the (10) limestone rock samples $(1 \mathrm{~S} 7,2 \mathrm{~S} 7$, 3S7, 1S8, 2S8, 1S9, 2S9, 3S9, 1S10 and 2S10) of the Fatha Formation

\begin{tabular}{|c|c|c|c|c|c|c|c|c|c|}
\hline $\begin{array}{l}\text { Solution } \\
\text { Type }\end{array}$ & $\begin{array}{r}\mathrm{pH} \\
\text { at } 28 \\
\pm 2^{\circ} \mathrm{C}\end{array}$ & $\begin{array}{l}\text { Element } \\
\text { Time } \\
\text { (day) }\end{array}$ & $\begin{array}{c}\mathrm{Ca}^{2+} \\
\mathrm{Ppm}\end{array}$ & $\begin{array}{r}\mathrm{Mg}^{2+} \\
\mathrm{ppm}\end{array}$ & $\begin{array}{l}\mathrm{Na}^{+} \\
\mathrm{ppm}\end{array}$ & $\begin{array}{c}\mathrm{K}^{+} \\
\mathrm{ppm}\end{array}$ & $\begin{array}{l}\mathrm{S}^{2-} \\
\mathrm{ppm}\end{array}$ & $\begin{array}{c}\mathrm{Cl}^{-} \\
\mathrm{ppm}\end{array}$ & $\frac{\mathrm{Ca}^{2+}}{\mathrm{Mg}^{2+}}$ \\
\hline \multirow{5}{*}{$\begin{array}{l}\text { Acidic } \\
(0.0001 \mathrm{~N} \\
\left.\mathrm{H}_{2} \mathrm{SO}_{4}\right)\end{array}$} & \multirow{5}{*}{2.2} & 1 & 5.1 & 6.2 & 1.9 & 17.3 & 4.2 & 3.2 & 0.82 \\
\hline & & 7 & 5.2 & 6.3 & 3.9 & 17.3 & 8 & 6.5 & 0.83 \\
\hline & & 14 & 5.2 & 6.3 & 9.5 & 38.9 & 20 & 6.8 & 0.83 \\
\hline & & 21 & 5.2 & 6.3 & 9.9 & 38.9 & 22 & 6.9 & 0.83 \\
\hline & & 28 & 5.4 & 6.3 & 9.9 & 38.9 & 22 & 7.2 & 0.86 \\
\hline \multirow{5}{*}{$\begin{array}{l}\text { Neutral } \\
\text { (Tap } \\
\text { Water) }\end{array}$} & \multirow{5}{*}{7.3} & 1 & 6.1 & 7.2 & 1.9 & 10.1 & 6 & 3.6 & 0.85 \\
\hline & & 7 & 6.2 & 7.3 & 1.9 & 17.3 & 8.4 & 12 & 0.85 \\
\hline & & 14 & 6.6 & 7.4 & 1.9 & 17.3 & 8.4 & 13 & 0.89 \\
\hline & & 21 & 9 & 9.3 & 2.3 & 24.5 & 12 & 13 & 0.97 \\
\hline & & 28 & 9.5 & 9.3 & 2.3 & 24.5 & 14 & 13 & 1.02 \\
\hline \multirow{5}{*}{$\begin{array}{l}\text { Alkaline } \\
(0.0001 \mathrm{~N} \\
\mathrm{NaOH})\end{array}$} & \multirow{5}{*}{10.3} & 1 & 3.2 & 4.1 & 6.7 & 17.3 & 4 & 3.2 & 0.78 \\
\hline & & 7 & 3.5 & 4.2 & 7.1 & 17.3 & 16 & 8.5 & 0.83 \\
\hline & & 14 & 3.8 & 4.3 & 7.1 & 17.3 & 20 & 8.9 & 0.88 \\
\hline & & 21 & 3.9 & 5.1 & 7.1 & 17.3 & 28 & 10.2 & 0.76 \\
\hline & & 28 & 4.2 & 5.2 & 7.1 & 17.3 & 32 & 12 & 0.81 \\
\hline
\end{tabular}


The $\mathrm{Ca}^{2+}$ concentration of the three types of solutions, which was determined, considered as a measure of dissolved gypsum or limestone in closed system at flow velocity equal zero and constant temperature. Therefore, the effect of solution-pH on the dissolution rate is greater as the time is increased. The results of the gypsum rocks (concentrations of $\mathrm{Ca}^{2+}$ and $\mathrm{S}^{2-}$ ) of the three types of experiments (Table 5) show that, the dissolution at the time 28 days was higher in alkaline environment than neutral (tap water) and acidic (Figs. 3, 4 and 5).

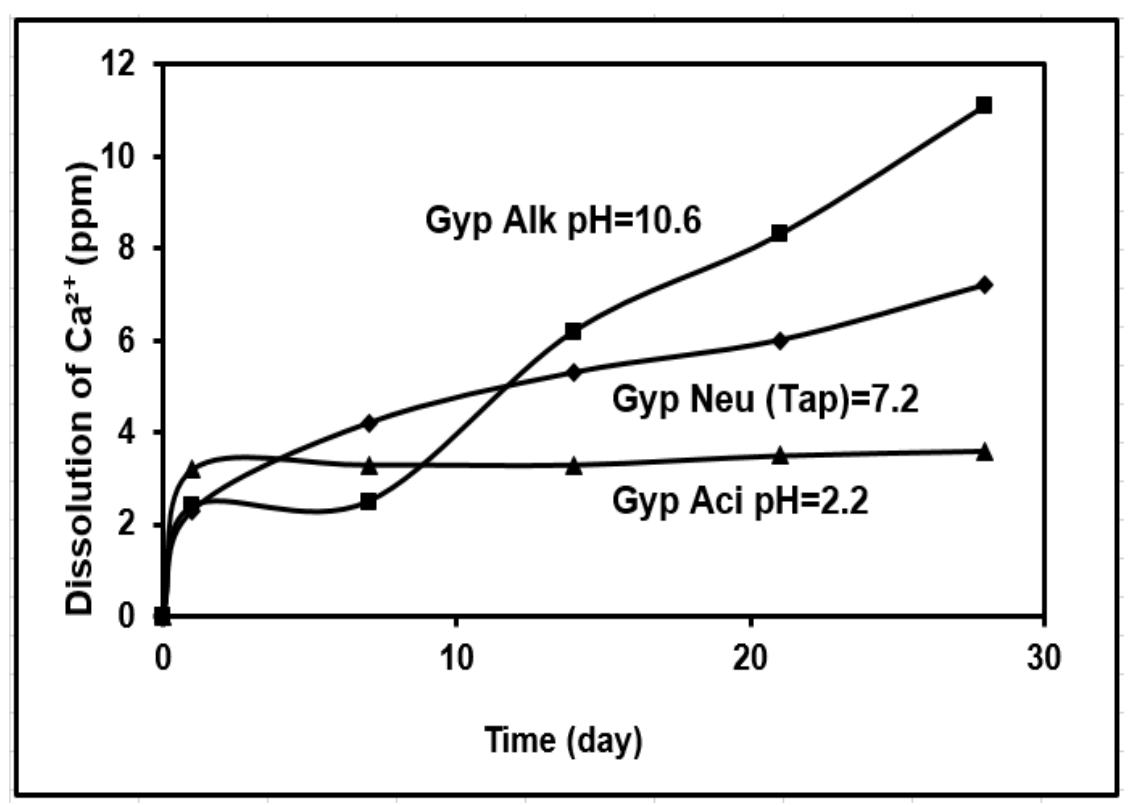

Fig. 3. Relation between time and concentration of calcium in three Solutions (acidic, neutral (tap water) and alkaline) of gypsum rocks

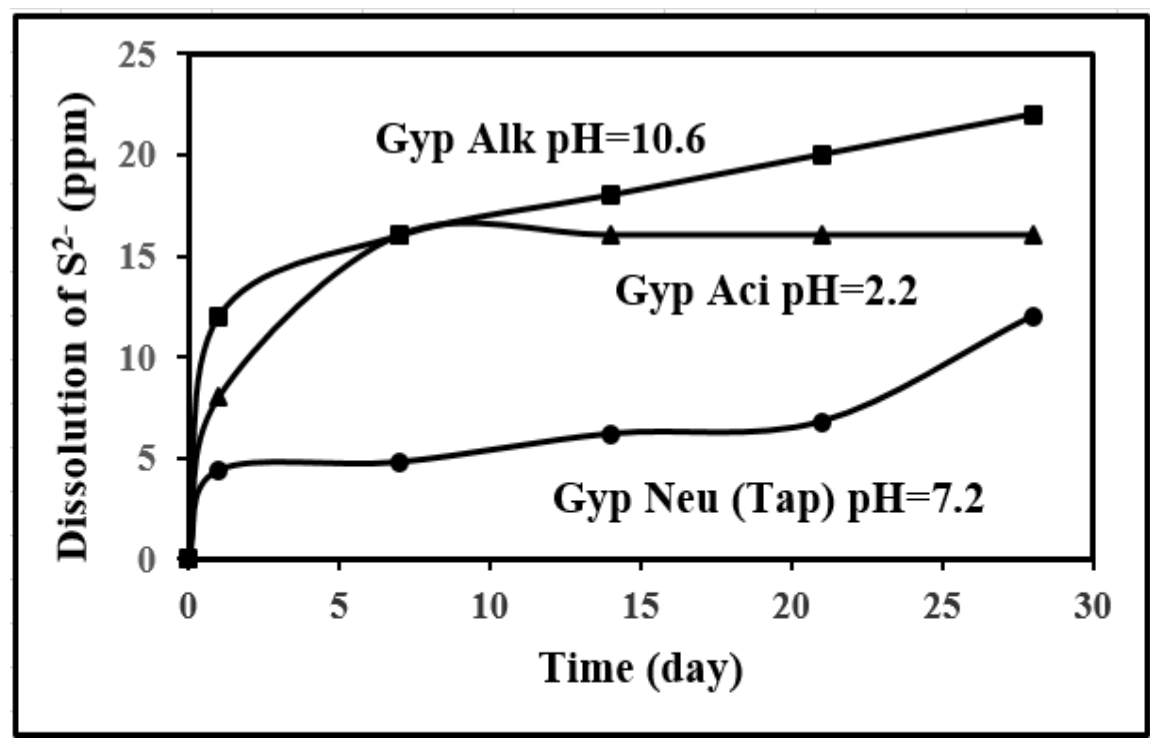

Fig. 4. Relation between time and concentration of sulphur in three solutions (acidic, neutral (tap water) and alkaline) of gypsum rocks 


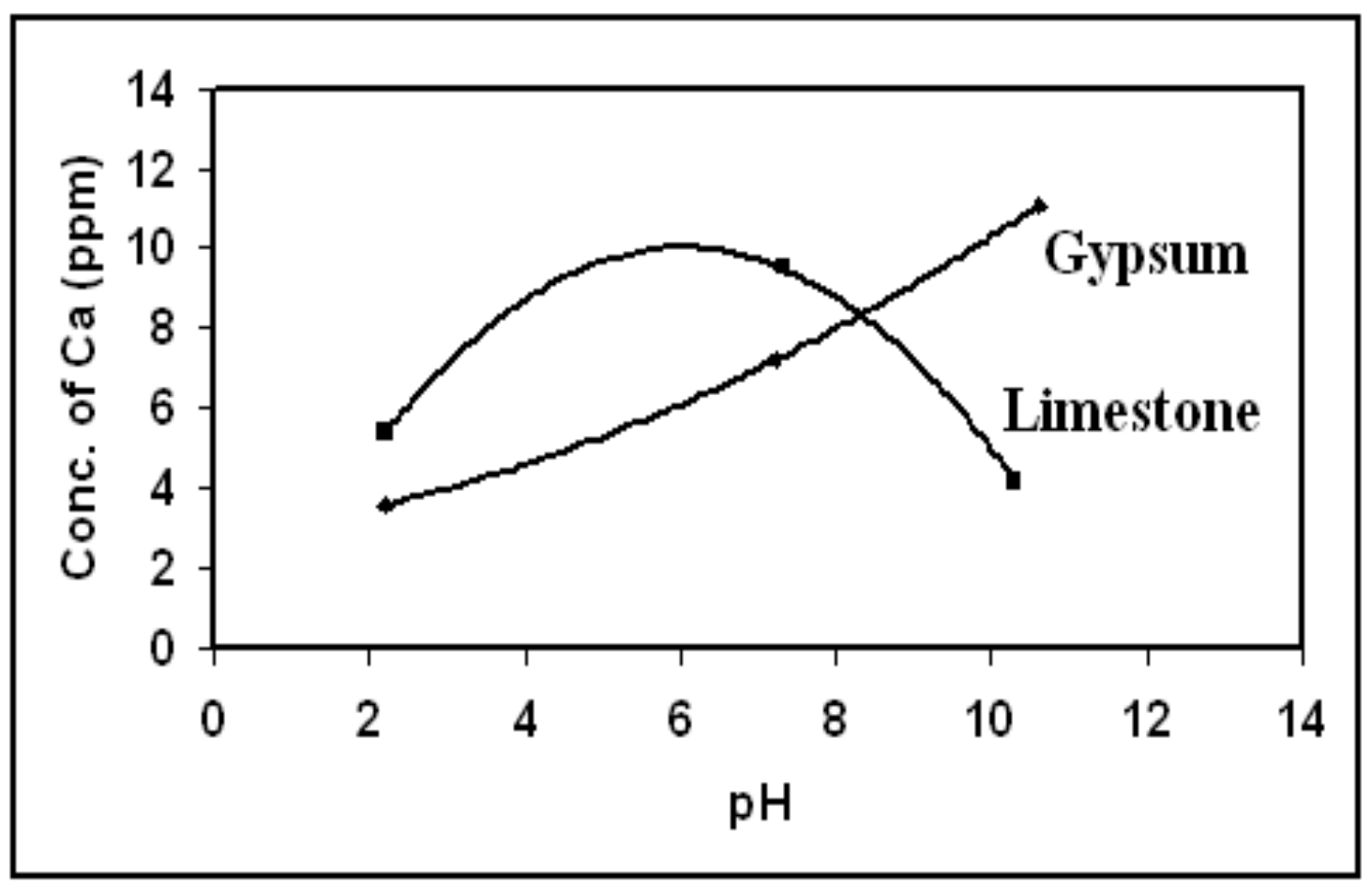

Fig. 5. Relation between $\mathrm{pH}$ and concentration of calcium in three solutions at time (28 days) of gypsum and limestone rocks

The gypsum rocks have other ions of salt combinations as $\left(\mathrm{Mg}^{2+}, \mathrm{Na}^{+}, \mathrm{K}^{+}\right.$and $\left.\mathrm{Cl}^{-}\right)$were dissolved also. The dissolution of gypsum and salts combination is not constant but increases with time (Al-Dabbagh, 1989; Al-Dabbagh et al., 1990; Aljubouri and Al-Kawaz, 2007). However, in the present study, the dissolution decreases in acidic solution (Table 5) and (Fig.3). Due to the common-ion effect, because the excess of $\mathrm{SO}_{4}{ }^{2-}$ would lower the solubility. So, the concentration becomes constant with longer time (Krauskopf, 1979; AlDabbagh, 1989 and Langmuir, 1997).

The results of the limestone ( $\mathrm{Ca}^{2+}$ concentrations) of the three types of solutions (Table 6) explain that, the dissolution was higher in neutral (tap water) environment than the other solutions (Figs. 5 and 6). The concentrations of $\mathrm{Ca}^{2+}, \mathrm{Mg}^{2+}$, and $\mathrm{Cl}^{-}$in neutral (tap water) solution at the time of 28 days were more than the concentrations in the alkaline and acidic solutions. The ions of salt combinations $\left(\mathrm{Na}^{+}, \mathrm{K}^{+}\right)$and $\left(\mathrm{S}^{2-}\right)$ have high concentrations in acidic and alkaline solutions respectively (Table 6).

Generally, dissolution of limestone is faster at low $\mathrm{pH}$ (acidic solution) especially at low acid concentration, so the acid dissolves calcium carbonate to form the very weak acid by reaction equation (Huminicki, 2006): $\mathrm{CaCO}_{3}+\mathrm{H}^{+} \rightarrow \mathrm{Ca}^{2+}+\mathrm{HCO}_{3}{ }^{-}$. The forward reaction shows, what happens when limestone subjected to weathering by acidic solution, the low $\mathrm{pH}$ 
accelerates weathering processes and dissolves to form caves (Krauskopf, 1979 and Sharma et al., 2006). The dissolution rate of limestone will decrease as the $\mathrm{pH}$ increasing (alkaline solution), because the hydroxide of alkaline solution reacts with bicarbonate which resulting from dissolving limestone (Lasaga et al., 1983). Because carbonate ion $\left(\mathrm{HCO}_{3}^{-}\right)$readily forms, can be reverse the process, represented by the precipitation of calcium carbonate (like common-ion effect). Therefore, the dissolving of limestone slows or stops (Krauskopf, 1979; Cravotta, 2005). Also, the limestone dissolves more slowly if it includes dolomite (Al-Kawaz, 2010 ), so that the ratio of $\left[\mathrm{Ca}^{2+}\right] /\left[\mathrm{Mg}^{2+}\right]$ does not show big variations in solution and tends to be close to unity (Langmuir, 1997; Martinez and White, 1999) as shown in Table 6. In the present study, the dissolution of limestone $\left(\mathrm{Ca}^{2+}\right.$ concentration) in acidic solution (low $\left.\mathrm{pH}\right)$ at the time of 28 days was low or constant.

Treatment limestone with sulfuric acid solution (low concentration) may be leads to formation secondary gypsum, $\mathrm{Ca}^{2+}$ react with $\mathrm{SO}_{4}{ }^{2-}$ according to the equation: $\mathrm{CaCO}_{3}+$ $\mathrm{H}_{2} \mathrm{SO}_{4}+2 \mathrm{H}_{2} \mathrm{O} \rightarrow \mathrm{CaSO}_{4} .2 \mathrm{H}_{2} \mathrm{O}+\mathrm{H}_{2} \mathrm{CO}_{3}$. This gypsum was coating the surface of limestone (or calcite), which may affect to decrease its dissolution rate over time (Oard, 1998; Alkattan et al., 1998 and Huminicki, 2004).

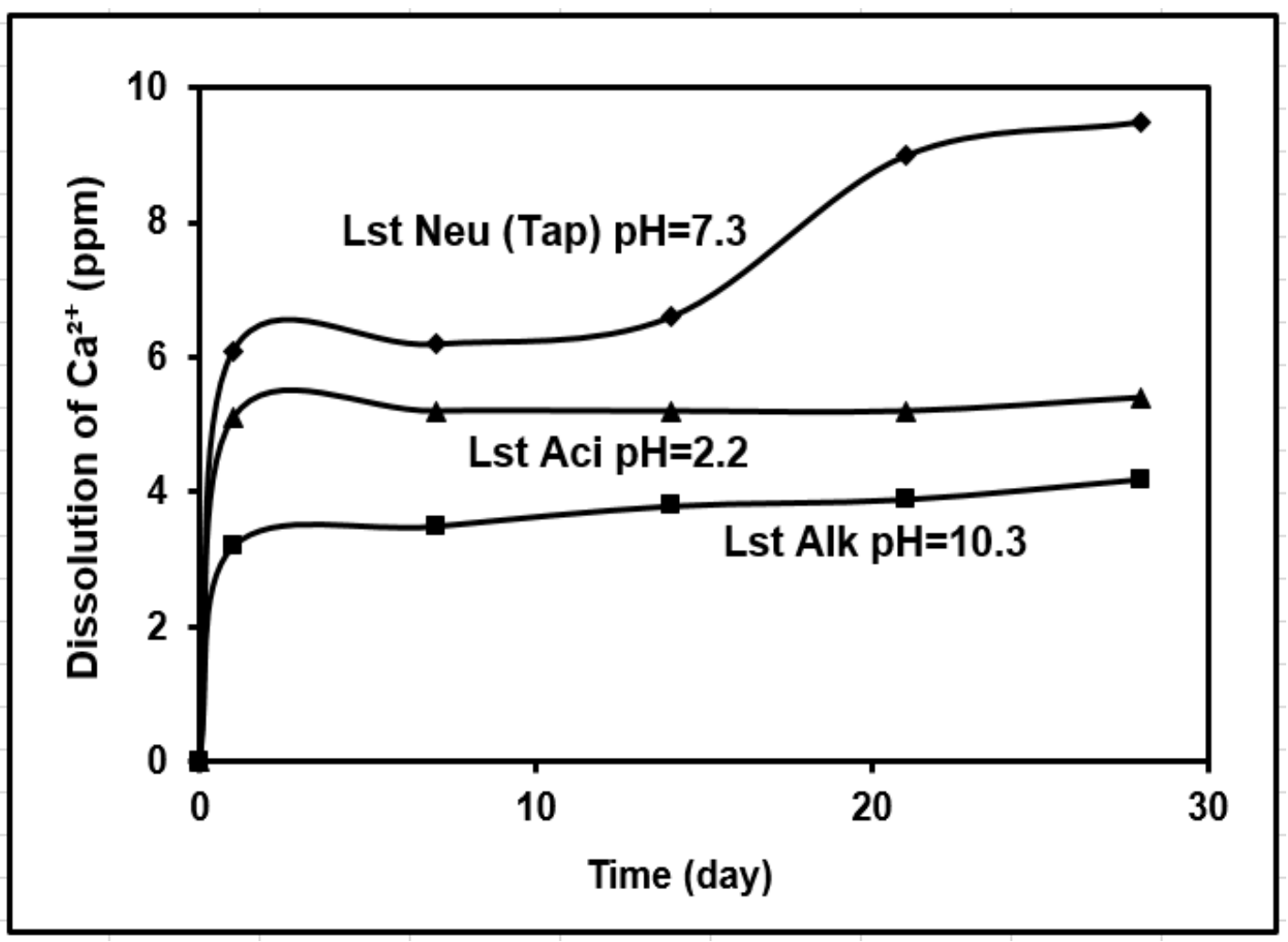

Fig. 6. Relation between time and concentration of calcium in three solutions (acidic, neutral (tap water) and alkaline) of limestone rocks 
Table 4 demonstrates the values of some physio-mechanical properties such as; uniaxial compressive strength, tensile strength, and specific gravity of gypsum and limeston rocks of the Fatha Formation from boreholes in the study area. As illustrated in Table 4, the means of compressive strength of wet samples of gypsum rocks decreased by $25.56 \%$, and of wet samples of limestone decreased by $23.97 \%$ when compared to the compressive strength means of dry samples. On the other hand, the means of indirect tensile strength of wet samples of gypsum rocks decreased by $36.62 \%$, and of wet samples of limestone decreased by $36.34 \%$ comparison to dry samples. Therefore, the dissolution of gypsum and limestone rocks may occur, when surface water from rains and other domestic uses goes underground, or from sewage and tap water leakage of main pipes.

The study expects that the physio-mechanical properties of rocks are adversely affected by the acidic and alkaline (different $\mathrm{pH}$ environments) moisture conditions (Sharma et al., 2006). A statistical technique (Regression analysis) was used in an attempt to explore and modeling the relationship between two or more variables. The regression-equation can check how good the model (in terms of predictive ability) by examining the coefficient of determination $\left(\mathrm{R}^{2}\right)$, the closer $\mathrm{R}^{2}$ is to one, the better is the model and its prediction (Navidi, 2008). Table 7 illustrates the statistical models, simple linear regression for the dissolution $\left(\mathrm{Ca}^{2+}\right.$ concentration) of gypsum rocks and limestone.

The high coefficient (regression sum of squares) of determination indicates good correlation, between the dissolution $\left(\mathrm{Ca}^{2+}\right.$ concentration) and other elements with time, so the alkaline solution for gypsum rocks has high S.S. of regression, because the dissolution rate increases at alkaline solution. While because the dissolution of limestone is high at neutral (tap water) solution, it has high value coefficient of determination (S.S. of regression) which indicates good correlation between the dissolution $\left(\mathrm{Ca}^{2+}\right.$ concentration) of limestone and other elements with time. The dissolved concentrations of the elements of rocks considered in the prediction of the rate of dissolution, which can consider the same as the rate of cavity formation. The high coefficient of determination such models may using to predict the degree of dissolution of the rocks with time, which will lead to the cavity formation. 
Table 7. Statistical data of gypsum and limestone rocks of the Fatha Formation

\begin{tabular}{|c|c|c|c|}
\hline $\begin{array}{l}\text { Rock type } \\
\text { and } \\
\text { Solution } \\
\text { Type }\end{array}$ & $\begin{array}{c}\text { Linear Regression Model by Stepwise } \\
\text { method }\end{array}$ & $\begin{array}{l}\text { Coefficient of } \\
\text { determination } \\
\left(\mathbf{R}^{2)}\right.\end{array}$ & $\begin{array}{c}\text { Regression } \\
\text { Sum of } \\
\text { squares } \\
\text { (S S R) }\end{array}$ \\
\hline $\begin{array}{l}\text { Gypsum } \\
\text { Acidic }\end{array}$ & $\begin{array}{c}\mathrm{Ca}=3.171+0.015 \text { Time }-0.507 \mathrm{Mg}- \\
0.093 \mathrm{Na}+0.117 \mathrm{~K}-0.093 \mathrm{~S}-0.452 \mathrm{Cl} \\
\mathrm{pH} \rightarrow \text { constant }\end{array}$ & 0.931 & 0.101 \\
\hline $\begin{array}{l}\text { Gypsum } \\
\text { Neutral } \\
\text { (Tap Water) }\end{array}$ & $\begin{array}{c}\mathrm{Ca}=1.850+0.131 \text { Time }-0.196 \mathrm{Mg}+ \\
0.082 \mathrm{Na}+0.058 \mathrm{~K}+0.091 \mathrm{~S}+0.081 \mathrm{Cl} \\
\mathrm{pH} \rightarrow \text { constant }\end{array}$ & 0.997 & 13.822 \\
\hline $\begin{array}{l}\text { Gypsum } \\
\text { Alkaline }\end{array}$ & $\begin{array}{c}\mathrm{Ca}=1.231+0.343 \mathrm{Time}-0.232 \mathrm{Mg}+ \\
0.148 \mathrm{Na}+0.070 \mathrm{~K}-0.874 \mathrm{~S}-0.407 \mathrm{Cl} \\
\mathrm{pH} \rightarrow \text { constant }\end{array}$ & 0.963 & 54.42 \\
\hline $\begin{array}{l}\text { Limestone } \\
\text { Acidic }\end{array}$ & $\begin{array}{c}\mathrm{Ca}=5.123+0.026 \mathrm{Time}-0.190 \mathrm{Mg}+ \\
0.251 \mathrm{Na}+0.619 \mathrm{~K}-0.134 \mathrm{~S}-0.234 \mathrm{Cl} \\
\mathrm{pH} \rightarrow \text { constant }\end{array}$ & 0.991 & 0.048 \\
\hline $\begin{array}{l}\text { Limestone } \\
\text { Neutral } \\
\text { (Tap Water) }\end{array}$ & $\begin{array}{c}\mathrm{Ca}=-4.502+0.220 \text { Time }+1.479 \mathrm{Mg}- \\
0.686 \mathrm{Na}+0.036 \mathrm{~K}+0.238 \mathrm{~S}+0.028 \mathrm{Cl} \\
\mathrm{pH} \rightarrow \text { constant }\end{array}$ & 0.985 & 10.547 \\
\hline $\begin{array}{l}\text { Limestone } \\
\text { Alkaline }\end{array}$ & $\begin{array}{c}\mathrm{Ca}=4.514+0.050 \mathrm{Time}-0.329 \mathrm{Mg}+ \\
0.055 \mathrm{Na}-0.037 \mathrm{~K}+0.158 \mathrm{~S}+0.092 \mathrm{Cl} \\
\mathrm{pH} \rightarrow \text { constant }\end{array}$ & 0.999 & 0.587 \\
\hline
\end{tabular}

\section{CONCLUSIONS}

The present study concludes:

1- The common-ion effect of sulfate ion in acidic solution $\left(0.0001 \mathrm{~N} \mathrm{H}_{2} \mathrm{SO}_{4}\right)$ decrease the dissolution or solubility (which represents the concentration of $\mathrm{Ca}^{2+} \& \mathrm{~S}^{2-}$ ) of gypsum, while the presence of $\mathrm{Na}^{+}$and $\mathrm{OH}^{-}$in alkaline solution $(0.0001 \mathrm{~N} \mathrm{NaOH})$ different from the ions of gypsum itself generally makes the gypsum more soluble.

2- Carbonate rocks are sensitive to acidic environments, but in the present study, the dissolution of limestone in acidic solution $\left(0.0001 \mathrm{~N} \mathrm{H}_{2} \mathrm{SO}_{4}\right)$ is low or constant. It may be due to the formation of secondary gypsum coating the surface of limestone. However, the alkaline solution makes the reaction of limestone to reverse the process 
of calcium carbonate precipitation, or carbonate are not sensitive to alkaline solution, so the dissolution of limestone slows or stops.

3- Dissolution of gypsum rocks in a closed system (at atmospheric pressure and at temperature $28 \pm 2^{\circ} \mathrm{C}$ ) is not a constant; it increases as the $\mathrm{pH}$ of the dissolving solution increases.

4- Analytical results (concentrations of $\mathrm{Ca}^{2+}, \mathrm{K}^{+}$, and $\mathrm{S}^{2-}$ ) of three various $\mathrm{pH}$ environmental conditions, of closed system (at atmospheric pressure and at temperature $28 \pm 2^{\circ} \mathrm{C}$ ) appears that the dissolution of the gypsum rocks was higher in alkaline environment, while the dissolution of the limestone (concentrations of $\mathrm{Ca}^{2+}$, $\mathrm{Mg}^{2+}$, and $\mathrm{Cl}^{-}$) was higher in neutral (tap water) environment than others solutions.

5- From the statistical models (simple linear regression), the high coefficient (regression sum of squares) of gypsum rocks is in alkaline solution, and of limestone is in neutral (tap water). It indicates good correlation between the dissolution ( $\mathrm{Ca}^{2+}$ concentration) and others elements with time, and could be used to predict the dissolution of rocks, which could be considered the same as the cavity formation.

6- The mean of compressive strength of wet samples of gypsum rocks decreased by $25.56 \%$, and of wet samples of limestone decreased by $23.97 \%$ when compared to the compressive strength mean of dry samples. On the other hand, the mean of indirect tensile strength of wet samples of gypsum rocks decreased by $36.62 \%$, and of wet samples of limestone decreased by $36.34 \%$ comparing to dry samples. Therefore, the progressive weakening of both strengths is due to the effect of water, which reduces the strength of the rocks.

7- The study expects that, the dissolution of gypsum and limestone rocks may occur, when surface water from rains and others domestic uses seep to underground, or from sewage and tap water leakage of main pipes. As well as, when sulphuric acid may form at depth due to the oxidation of sulphur by acidophilic bacteria. The prevention of surface water seepage into the ground is important. Surface water should be piped away by establish surface water drainage to avoid the rapid subsidence of unstable deposits over cavities in the karst.

\section{ACKNOWLEDGMENTS}

The authors are very grateful to the University of Mosul, College of Science, and National Center for Construction Laboratories and Researches, Nineveh Construction Laboratory, for their provided facilities, which helped to improve the quality of this work. The authors are 
very grateful to the Editor in Chief Prof. Dr. Salih M. Awadh, the Secretary of Journal Mr.

Samir R. Hijab and the Technical Editor Dr. Heba S. Al-Mimar for their great efforts and valuable comments.

\section{REFERENCES}

Adeeb, H. G. M., 1988. Structure and Stratigraphy of Mosul City-The Right Bank. Unpublished M.Sc. thesis, University of Mosul, 168P (In Arabic).

Al-Dabbagh, S. M., 1989. The solubility of Gypsum and Anhydrite in Close System for the Site of the Saddam Dam. Saddam Dam Research Centre, Mosul University, Iraq, 11P (In Arabic).

Al-Dabbagh, T.H., Elias, E. M., and Khaleel, M. S., 1990. Determination of the rate of Dissolution of Gypsum and Anhydrite from Saddam Dam foundation. Proceeding $2^{\text {nd }}$ Science Conference of Saddam Dam Research Centre, Mosul University, Mosul-Iraq, 18-20 March 1990: 341-353.

Aljubouri, A. I., Al-Naqib, S.Q., and Al-Traif, A. S. M., 2006. Mineralogical and geochemical study of the subsurface acidification products Ninevite, alunite and jarosite, Northern Iraq. Arab Journal of Basic and Applied, university of Bahrain.

Aljubouri, Z. A., 2011. Geochemistry of calcium sulphate rocks of Fatha Formation at four localities within Nineveh district, Northern Iraq (with emphasis on strontium distribution). Iraqi National Journal of Earth Science, 11(1): 49-70.

Aljubouri, Z. A., and Al-Kawaz, H. A., 2007. Dissolution rate of gypsum under different environments. Iraqi Journal of Earth Science, 7 (2): 11-18.

Aljubouri, Z. A., and Khattab, S. A., 1997. The dissolution of calcium sulphate rocks below the foundation of a large hydraulic structure. Rafidain Journal Science, 8 (1): 63-73.

Alkattan, M., Oelkers, E. H., Dandurand, J. L., and Schott, J., 1998. An Experimental study of calcite and limestone dissolution rates as a function of $\mathrm{pH}$ from 1 to 3 and temperature from 25 to $80^{\circ} \mathrm{C}$. Chemical Geology, 151: 199-214.

Al-Kawaz, H.A., 2010. Dissolution rate constant of carbonates under natural environments. Tikrit journal of pure science, 15 (3): 84-90.

Al-Taa'i, A. M. M., 2002. The Mineralogical Variations and the Influence of Iron-sulfur oxidizing Bacteria on the River Terraces Section-south of Mosul. M. Sc. thesis, University of Mosul, 122P (In Arabic).

APHA, A. W. W. A., and W. P. C. F., 1976. Standard Methods for the Examination of Water and Wastewater. American Public Health Association, American Water Works Association and Water Pollution Control Federation, Washington DC, $14^{\text {th }}$ Ed., 1193P.

ASTM, C97., 2002. Standard Test Methods for Absorption and Bulk Specific Gravity of Dimension Stone.

ASTM, C97-96, 1-3P in: Annual Book of ASTM (American Society for Testing and Materials) Standard, Building seals and Sealants fire Standards Dimension Stone, 04.07.

ASTM, D2938, 2002. Standard Test Method for Unconfined Compressive Strength of Intact Rock Core Specimens. ASTM D2938-95, 1-3P in: Annual Book of ASTM (American Society for Testing and Materials) Standard, Soil and Rock, 04.08.

ASTM, D3967, 2001. Standard Test Method for Splitting Tensile of Intact Rock Core Specimens.

ASTM, D3967-95a, 1-3P in: Annual Book of ASTM (American Society for Testing and Materials) Standard, Soil and Rock, 04.08.

Awadh, S. M., and Al-Ankaz, Z. S., 2016. Inorganic geochemistry and origin of bitumen intruded in Euphrates and Fatha Formations in Hit Area, Western Iraq. Iraqi Journal of Science, 57 (4A): 2478-2489.

Craft, C. D., Pearson, R. M., and Hurcomb, D., 2007. Mineral dissolution and dam seepage chemistry-The Bureau of Reclamation Experience. U.S. Department of the interior, Bureau of Reclamation, Technical service center, Denver Federal center, Colorado, presented at the Association of State Dam Safety Officials Annual Conference (ASDSO), Austin, Texas, 38P.

Cravotta, C. A., 2005. Limestone dissolution in passive systems for neutralization of acidic mine drainage. U.S. Geological survey, New Cumberland, Pennsylvania, Mine water Treatment Technology Conference, Pittsburgh. 
Galloway, D., Jones, D. R., and Ingebrigtsen, S. E., 1999. Land subsidence in the United States. Part III, collapsing Cavities: 107-140. U.S. Geological survey, U.S. Department of the interior, 175P.

Huminicki, D. M. C., 2004. The effect of gypsum coatings on the dissolution rate of calcite in AMD solutions. Denver Annual Meeting, Geological Society of America, Abstracts with Programs, 36, 5: 558.

Huminicki, D. M. C., 2006. Effect of Coatings on Mineral Reaction Rates in Acid Mine Drainage. Ph.D. Dissertation, Virginia polytechnic institute and state university, Blacksburg, Virginia, 89P.

Ismail, S. A., and Al-Naib, M., 1992. Surface soil map of Mosul. Report of National Center for Construction Laboratories and Researches, Iraq.

ISW, 2012. Institute for the study of war, Map of Mosul. In: https://www.understandingwar.org/map/map-mosul.

Jassim, S. Z. and Al-Naqib, S. Q., 1989. Ninivite; A new form of porcelainite and the associated Alunite and Jarosite minerals. A suite related to Sulphuric acid seepages south of Mosul, Northern Iraq. Journal Geological Society of Iraq, 22 (1): 112-122.

Jassim, S. Z. and Buday, T., 2006. Units of the Unstable Shelf and the Zagros Suture. (CH.6) In: Jassim, S.Z. and Goff, J.C., 2006. Geology of Iraq. Published by Dolin, Prague and Moravian, Museum Brno Czech Republic, 341P.

Krauskopf, K. B., 1979. Introduction to Geochemistry. Second edition, McGraw-Hill, Inc., 617P.

Langmuir, D., 1997. Aqueous Environmental Geochemistry. Prentice- Hall, Inc., 600P.

Lasaga, A. C., Berner, R. A., Fisher, G. W., Anderson, D. E., and Kirkpatrick, R. J., 1983. Kinetics of geochemical processes. Reviews in mineralogy, V. 8, Mineralogical society of America. Series Editor, Ribbe, P.H., $2^{\text {nd }}$ printing, 398P.

Martinez, M. I., and White, W. B., 1999. A laboratory investigation of the relative dissolution rates of the Lirio limestone and the ISLA DE MONA dolomite and implications for cave and karst development on ISLADEMONA. Journal of Cave and Karst studies, 61(1): 7-12.

Navidi, W., 2008. Statistics for engineers and scientists. Second Edition, McGraw-Hill Companies, Inc., 901P. Oard, M., 1998. Rapid cave formation by sulfuric acid dissolution. Technical Journal of Creation, December, 1 .

Nu, N. T., Duong, N. T., Son, B. T., and Thinh, P. H., 2020. Investigation of salt, alum content in soft soils and their effects on soil properties: case study in coastal areas of Vietnam. Iraqi Geological Journal, 53 (2A), 2020: 19-34.

Sharma, P. K., Khandelwal, M., and Singh, T. N., 2006. Effect of acidic water on physio-mechanical properties of building stone: a case study. Department of Earth science, IAEG, 514.

Sissakian, V. K., and Abdul-Jabbar, M. F., 2005. Site selection problems in Gypsum-bearing formations. A case study from North of Iraq. Iraqi Bulletin of Geology and Mining, 1(2): 45-51.

Sissakian, V. K., and Al-Mousawi, H. A., 2007. Karstification and related problems, examples from Iraq. Iraqi Bulletin of Geology and Mining, 3(2): 1-12.

Thabet, K. M., Al-Ashou, M. O., and Al-Khashab, M. N., 1986. Some effects of cavities on the stability of buildings in Mosul city. Journal of the Geological Society of Iraq, 19: 2.

Tobia, F. H., and Mustafa, B. H., 2019. Provenance and depositional environment of the carbonates from Baluti Formation (Late Triassic), Kurdistan Region, Iraq. Iraqi geological Journal, 52(2): 18-35.

Wikimedia Commons, 2020. Atlas of Iraq from Wikimedia Commons Atlas of the world. In: https://www.commons.wikimedia.org/wiki/Atlas of Iraq. 